\title{
A STUDY OF MICROBIAL ANALYSIS OF FRESH FRUITS AND VEGETABLES, IN SAGAMU MARKETS SOUTH-WEST, NIGERIA.
}

\author{
${ }^{1}$ Adekanle M.A, ${ }^{2}$ Effedua H. I, ${ }^{3}$ Oritogun K. S, ${ }^{1 *}$ Adesiji Y.O, and ${ }^{4}$ Ogunledun A, \\ ${ }^{1}$ Department of Medical Microbiology \&Parasitology, College of Health Sciences, Ladoke \\ Akintola University of Technology, Ogbomosho.Nigeria \\ ${ }^{2}$ Department of Medical Microbiology \& Parasitology Babcock University, llesan Remo, llesan. \\ Ogun State, Nigeria \\ ${ }^{3}$ Department of Medical Microbiology \& Parasitology Olabisi Onabanjo University \\ ${ }^{4}$ Obafemi Awolowo college of Health Sciences, Sagamu.Ogun State. Nigeria \\ *Correspondence: drmsadesiji@yahoo.com \\ Telephone number; 08032948270
}

\begin{abstract}
S
Raw and minimally processed fruits and vegetables are essential parts of diets of people around the world. However, these food items have consistently served as vehicles for human diseases worldwide. This study was aimed at determining the microbiological quality of fresh fruits and vegetables sold at Sagamu markets, Ogun state, Nigeria. Twenty different samples of fruits and vegetables were randomly purchased from ten various vendors in Shagamu market, Ogun State, Nigeria. Aerobic plate counts, total coliform counts, yeast, mold counts and antimicrobial susceptibility study using were determined using standard microbiological methods. In Fruits, the isolation rate of Bacillus specie was predominant (44.1\%), followed by Klebsiella species (44.0\%) while in vegetables, the prevalent rates of $38.3 \%$ and $14.4 \%$ were respectively recorded by Staphylococcus aureus and Pseudomonas species. Malassezia species and Aspergillus species were the only fungal isolates obtained from the fruits and vegetables. Aspergillus species were predominant in vegetables, with a frequency of $13.3 \%$ while both Malassezia and Aspergillus species were observed almost at the same frequently of $24.1 \%$ and $24.4 \%$ in fruits respectively. This study showed that fruits and vegetable were contaminated with potential food borne pathogens with varying degree of antibiotic resistance thus suggesting that they could act as a vehicle for the dissemination of antibiotic resistant organisms as well as serve as a reservoir of food borne pathogens of public health significance.
\end{abstract}

Keywords: Micro flora, fresh fruits and vegetables, antibiotics resistance,

\section{INTRODUCTION}

Fresh fruits and vegetables are a constant part of the daily diets of Nigerians, and are known for their high nutritional and health values, with fruits and vegetables being excellent source of essential 
nutrients (Senjuti et al., 2014). However, the contamination of fresh produce is a major public concern, as food borne diseases are increasingly becoming a global public health problem (Hannan et al., 2014), resulting in a tangible amount of morbidity and mortality annually worldwide (Hanson et al., 2012). Also the agricultural sector of Nigeria is a major contributor to its development (Fatoba et al., 2011) thus food loss is a major concern. Microbial contamination of fruits and vegetables regularly occurs in plantation fields, contact with soil, dust, contaminated irrigation water and use of raw sewage or manure fertilizers (Jung et al., 2014; Razzaq et al., 2014; Senjuti et al., 2014; Hannan et al., 2014). The process of transporting these food products from the farm to households also contributes to the contamination of these fruits and vegetables, thus posing a serious problem in food safety (Isa et al., 2014).

Various pathogens are associated with the contamination of fruits and vegetables, with different outbreaks of gastroenteritis related, associated with the consumption of contaminated vegetables have been recorded at various times (Jeddi et al., 2014). Pathogens implicated in contamination of fruits and vegetables include; Escherichia coli, Salmonella spp., Listeria monocytogenes, Aeromonas spp., Staphylococcus spp., Streptococcus spp., Vibrio spp. and Pseudomonas spp (Nwachukwu and Chukwu, 2013; Senjuti et al., 2014). In developing countries, food borne illness caused by contaminated fruits and vegetables are frequent but rarely properly documented and reported due to many reasons such as poor diagnostic facilities and lack of food borne disease investigation and surveillance. In Nigeria, Hazard Analytic Critical Control Point (HACCP) is not implemented thus, fruits and vegetables are grown with untreated human and animal wastes, transported and sold by local farmers or retail outlets for further processing by street vendors, by families at home or as part of meals eaten in restaurant and other eatery outlets (Eni et al., 2010), with this practice being pointed out to be one of the major contributing factors to high level of contamination of farm produce in Nigeria (Olayemi, 2007).

Studies of vegetables and fruits microbial contamination consumed by most people and their degree of resistance against a panel of antibiotics, will give an indication as to the resistance pattern of bacteria associated with raw vegetables and fruits in the study area, and can help identify potential sources of drug-resistant strains in Nigeria. Results obtained from this study can also be referred to in order to draw inference about the conditions of farm produce in Nigeria and possible links with spread to humans. 
Adekanle, Effedua, Oritogun, Adesiji \& Ogunledun

\section{MATERIALS AND METHODS}

\section{Sample collection and processing}

Sagamu is a popular town in Ogun State and one of the fast growing towns in South- west Nigeria. A total of Four hundred samples of assorted kinds of fruits and vegetables were purchased from different sellers at different fruit markets in Sagamu. 20 types of each fruit from 11 different handlers (220) and 20 types of each vegetable from 9 different handlers (180) were procured from these markets. To prevent post service contamination, the market sellers were instructed to dispense the samples into pre-sterilized metallic containers with lids. All samples were labelled and transported to the Medical Microbiology and Parasitology Laboratory of Olabisi Olabanjo University, Sagamu, for immediate processing. Fruits and vegetable samples were first swab in Nutrient Broth, and Selenite F broth overnight and then culture on, Blood Agar, MacConkey Agar, Manittol Salt Agar, and for Selenite F' Broth was culture on Salmonella Shigella Agar, for fungi isolation also on Potato Dextrose Agar for myco-flora isolation. Microbial identification was carried out in line with the Standard Methods for Microbiological Examination of Foods (SMMEF), as reported by Vanderzant and Splittstoesser (1993). Malassezia isolates were identified according to the specification of Downes and Ito (2001). Antimicrobial Susceptibility test for bacterial isolates was conducted using standard disc diffusion method. Statistical analysis was carried out using SPSS version 17.

\section{RESULTS}

Table 1 shows the relative distribution of Gram positive bacterial isolates in fruits and vegetables. In fruits Bacillus species had the highest isolation rate of $44.0 \%$, followed by Staphylococcus aureus (38.3\%). The situation was reversal in vegetables where Staphylococcus aureus was predominant with a frequency of $38.3 \%$, followed by Bacillus species. From the vegetables and fruits and $S$. aureus was isolated most from Slim banana (Fruit) and Onion (vegetable), $S$. epidermidis was isolated most from Orange (Fruit), Ugwu (Vegetable) and Bacillus sp was isolated most from grape and paw-paw (fruit) and cabbage and carrot (vegetables). 
Table1: Distribution of gram positive bacteria in fresh Nigerian fruits and vegetables

\begin{tabular}{|c|c|c|c|c|c|c|c|}
\hline Farm produce & \multicolumn{3}{|c|}{ S. aureus } & \multicolumn{2}{|c|}{ S. epidermidis } & \multicolumn{2}{|c|}{ Bacillus species } \\
\hline Fruits & & & & & & & \\
\hline African cherry & 20 & 7 & $(35.0)$ & 3 & $(15.0)$ & 0 & $(0)$ \\
\hline Fat banana & 20 & 11 & $(55.0)$ & 6 & $(30.0)$ & 3 & $(15.0)$ \\
\hline Slim banana & 20 & 15 & $(75.0)$ & 5 & $(25.0)$ & 13 & $(65.0)$ \\
\hline Grape & 20 & 0 & (0) & 0 & (0) & 10 & $(50.0)$ \\
\hline Lime & 20 & 10 & $(50.0)$ & 0 & (0) & 18 & $(80.0)$ \\
\hline Mango & 20 & 13 & $(65.0)$ & 0 & (0) & 0 & (0) \\
\hline Orange & 20 & 7 & $(35.0)$ & 7 & $(35.0)$ & 2 & $(10.0)$ \\
\hline Paw-Paw & 20 & 10 & $(50.0)$ & 0 & (0) & 13 & $(65.0)$ \\
\hline Pear & 20 & 0 & $(0)$ & 0 & $(0)$ & 16 & $(80.0)$ \\
\hline Pineapple & 20 & 0 & (0) & 0 & $(0)$ & 10 & $(50.0)$ \\
\hline Tomato & 20 & 8 & $(40.0)$ & 0 & (0) & 12 & $(60.0)$ \\
\hline Total & 220 & 81 & $(36.8)$ & 21 & $(9.6)$ & 97 & $(44.0)$ \\
\hline Vegetables & & & & & & & \\
\hline Cabbage & 20 & 0 & (0) & 0 & $(0)$ & 10 & $(50.0)$ \\
\hline Carrot & 20 & 0 & (0) & 0 & (0) & 10 & $(50.0)$ \\
\hline Cucumber & 20 & 13 & $(65.0)$ & 0 & $(0)$ & 2 & $(10.0)$ \\
\hline Garden Egg & 20 & 7 & $(35.0)$ & 7 & $(35.0)$ & 7 & $(35.0)$ \\
\hline Lettuce & 20 & 0 & (0) & 0 & (0) & 0 & $(0)$ \\
\hline Onion & 20 & 15 & $(75.0)$ & 5 & $(25.0)$ & 0 & (0) \\
\hline Water Leaf & 20 & 12 & (60.0) & 8 & $(40.0)$ & 0 & (0) \\
\hline Water Mellon & 20 & 12 & $(60.0)$ & 4 & $(20.0)$ & 16 & $(80.0)$ \\
\hline Ugwu & 20 & 10 & $(50.0)$ & 10 & $(50.0)$ & 0 & (0) \\
\hline Total & 180 & 69 & (38.3) & 34 & (18.9) & 45 & $(25.0)$ \\
\hline
\end{tabular}

$\mathrm{N}=$ Total number of fruit/vegetable samples

$n=$ Frequency of isolation from the fruit/vegetables samples

Table 2 demonstrates the frequency of Gram negative bacterial isolates in fruits and vegetables. Klebsiella species was the predominant isolate in fruits, recording a frequency of $40 \%$ while in vegetables, Pseudomonas species were prevalent, with a frequency of $14.4 \%$. Only Malassezia 
and Aspergillus species were isolated as myco-flora of fruits and vegetables. In fruits, both Malassiezia and Aspergillus species had a close prevalence rates of $24.1 \%$ and $21.4 \%$ respectively while Aspergillus species were the predominant isolates in vegetables, with a frequency of $13.3 \%$ (Table 3).

Table 2: Gram negative bacteria isolated from fresh Nigerian fruits and vegetables.

\begin{tabular}{|c|c|c|c|c|c|c|c|c|c|}
\hline \multirow[t]{2}{*}{ Farm produce } & \multirow[b]{2}{*}{$\mathrm{N}$} & \multicolumn{2}{|c|}{$\begin{array}{l}\text { Klebsiella } \\
\text { species }\end{array}$} & \multicolumn{2}{|c|}{$\begin{array}{l}\text { Proteus } \\
\text { species }\end{array}$} & \multicolumn{2}{|c|}{$\begin{array}{l}\text { Pseudomonas } \\
\text { species }\end{array}$} & \multirow{2}{*}{\multicolumn{2}{|c|}{$\begin{array}{l}\text { Escherichia coli } \\
n \quad(\%)\end{array}$}} \\
\hline & & $n$ & (\%) & $n$ & $(\%)$ & & & & \\
\hline \multicolumn{10}{|l|}{ Fruits } \\
\hline African cherry & 20 & 7 & (35.0) & 3 & $(15.0)$ & 3 & $(15.0)$ & 3 & $(15.0)$ \\
\hline Slim banana & 20 & 9 & $(45.0)$ & 3 & (15.0) & 0 & (0) & 3 & $(15.0)$ \\
\hline Fat banana & 20 & 18 & $(80.0)$ & 9 & $(45.0)$ & 0 & (0) & 0 & (0) \\
\hline Grape & 20 & 0 & (0) & 0 & (0) & 0 & (0) & 0 & (0) \\
\hline Lime & 20 & 16 & $(80.0)$ & 0 & (0) & 0 & (0) & 0 & (0) \\
\hline Mango & 20 & 0 & (0) & 0 & (0) & 8 & $(40.0)$ & 8 & $(40.0)$ \\
\hline Orange & 20 & 12 & $(60.0)$ & 0 & (0) & 2 & $(10.0)$ & 2 & $(10.0)$ \\
\hline Paw-paw & 20 & 13 & (65.0) & 0 & (0) & 0 & (0) & 0 & (0) \\
\hline Pear & 20 & 4 & $(20.0)$ & 6 & $(30.0)$ & 2 & $(10.0)$ & 2 & $(10.0)$ \\
\hline Pineapple & 20 & 3 & (15.0) & 3 & $(15.0)$ & 0 & (0) & 0 & (0) \\
\hline Tomato & 20 & 6 & $(30.0)$ & 0 & (0) & 0 & (0) & 0 & (0) \\
\hline Total & 220 & 88 & $(40.0)$ & 24 & (10.9) & 18 & (8.2) & 18 & (8.2) \\
\hline \multicolumn{10}{|l|}{ Vegetables } \\
\hline Cabbage & 20 & 0 & (0) & 0 & (0) & 5 & $(25.0)$ & 0 & (0) \\
\hline Carrot & 20 & 11 & $(55.0)$ & 0 & (0) & 0 & (0) & 0 & (0) \\
\hline Cucumber & 20 & 0 & (0) & 0 & (0) & 0 & (0) & 0 & (0) \\
\hline Garden Egg & 20 & 0 & (0) & 0 & (0) & 0 & (0) & 0 & (0) \\
\hline Lettuce & 20 & 0 & (0) & 0 & (0) & 0 & (0) & 0 & (0) \\
\hline Onion & 20 & 0 & (0) & 0 & (0) & 0 & (0) & 0 & (0) \\
\hline Water leaf & 20 & 0 & (0) & 0 & (0) & 0 & (0) & 0 & (0) \\
\hline Water melon & 20 & 0 & (0) & 0 & (0) & 16 & $(80.0)$ & 0 & (0) \\
\hline Ugwu & 20 & 0 & (0) & 0 & (0) & 5 & (25.0) & 0 & (0) \\
\hline Total & 180 & 11 & $(6.0)$ & 0 & (0) & 26 & (14.4) & 0 & $(0.0)$ \\
\hline
\end{tabular}

$\mathrm{N}=$ Total number of fruit/vegetable samples

$n=$ Frequency of isolation from the fruit/vegetables samples 
Adekanle, Effedua, Oritogun, Adesiji \& Ogunledun

Table 3: Fungi isolated from fresh Nigerian fruits and vegetables.

\begin{tabular}{|c|c|c|c|}
\hline \multirow[t]{2}{*}{ Farm Produce } & & Malassezia species & Aspergillus species \\
\hline & $\mathrm{N}$ & $(\%)$ & $(\%)$ \\
\hline
\end{tabular}

Fruits

$\begin{array}{llllll}\text { African cherry } & 20 & 13 & (65.0) & 7 & (35.0) \\ \text { Fat banana } & 20 & 0 & (0) & 3 & (15.0) \\ \text { Slim banana } & 20 & 0 & (0) & 0 & (0) \\ \text { Grape } & 20 & 17 & (75.0) & 3 & (15.0) \\ \text { Lime } & 20 & 10 & (50.0) & 10 & (50.0) \\ \text { Mango } & 20 & 0 & (0) & 4 & (20.0) \\ \text { Orange } & 20 & 0 & (0) & 0 & (0) \\ \text { Paw-Paw } & 20 & 0 & (0) & 0 & (0) \\ \text { Pear } & 20 & 10 & (50.0) & 10 & (50.0) \\ \text { Pineapple } & 20 & 3 & (15.0) & 10 & (50.0) \\ \text { Tomato } & 20 & 0 & (0) & 0 & (0) \\ \text { Total } & 220 & 53 & (24.1) & 47 & (21.4)\end{array}$

Vegetables

$\begin{array}{llllll}\text { Cabbage } & 20 & 0 & (0) & 0 & (0) \\ \text { Carrot } & 20 & 0 & (0) & 5 & (25.0) \\ \text { Cucumber } & 20 & 0 & (0) & 0 & (0) \\ \text { Garden Egg } & 20 & 0 & (0) & 10 & (50.0) \\ \text { Lettuce } & 20 & 0 & (0) & 0 & (0) \\ \text { Onion } & 20 & 3 & (15.0) & 0 & (0) \\ \text { Water Leaf } & 20 & 0 & (0) & 0 & (0) \\ \text { Water Mellon } & 20 & 4 & (20.0) & 4 & (20.0) \\ \text { Ugwu } & 20 & 0 & (0) & 5 & (25.0) \\ \text { Total } & 180 & 7 & (3.9) & 24 & (13.3)\end{array}$

$\mathrm{N}=$ Total number of fruit/vegetable samples

$n=$ Frequency of isolation from the fruit/vegetables samples 
Higher resistance was recorded against Cephalosporins (Ceftazidine $=100 \%$, Cefuroxine $=95.9 \%$ ) than in the Quinolones (Table 4). In Table 5, a comparative analysis of mean zones of Ofloxacin inhibition against Gram positive bacterial isolates showed a significant difference ( $F=5.66$, $\mathrm{P}<0.05)$; with Staphylococcus epidermidis having the highest resistance to Ofloxacin. Among the Gram negative bacterial isolates, a significant difference was observed in the comparative mean zone of Pefloxacin inhibition ( $F=5.38, P<0.05)$. Results further revealed that Pseudomonas aeruginosa was the most resistant isolate to Pefloxacin (Table 6).

Table 4: Antimicrobial resistance of fruits and vegetables.

\begin{tabular}{lllll}
\hline & & Resistance & $\begin{array}{l}\text { Percentage } \\
\text { resistance } \\
(\%)\end{array}$ \\
Antibacterial agent & $\mathrm{N}$ & $\mathrm{N}$ & $(1.1)$ \\
\hline $\begin{array}{l}\text { Quinolones } \\
\text { Ciprofloxacin (CIP) }\end{array}$ & 532 & 6 & $(3.8)$ \\
Perfloxacin (PEF) & 532 & 47 & $(5.5)$ \\
Ofloxacin (OFX) & 532 & 29 & $(26.5)$ \\
Sperfloxacin (SPM) & 532 & 141 & \\
$\begin{array}{l}\text { Cephalosporin } \\
\text { Cefuroxime (CXM) }\end{array}$ & 532 & 510 & $(95.9)$ \\
Ceftazidime (CAZ) & 532 & 532 & $(100.0)$ \\
\hline
\end{tabular}

$\mathrm{N}=$ number of bacteria challenged with antibiotic.

$\mathrm{n}=$ number of resistant bacteria. 
Table 5: Comparative antibiotic susceptibility of gram positive bacteria isolated From fresh fruits and vegetables.

\begin{tabular}{cllllll}
\hline $\begin{array}{l}\text { Antimicrobial } \\
\text { Agents }\end{array}$ & $N$ & Bacterial Isolates & $\begin{array}{l}\text { Zones of } \\
\text { inhibition } \\
\text { Mean } \pm \text { SD }\end{array}$ & $F$ & $P$-value & $\begin{array}{l}\text { Most resistant } \\
\text { isolate by LSD }\end{array}$ \\
\hline Ciprofloxacin & 55 & S. aureus & $24.23 \pm 1.50$ & & & \\
(CIP) & 136 & Bacillus species & $\begin{array}{l}22.88 \pm 1.73 \\
22.30 \pm 3.37\end{array}$ & 4.36 & $>0.05$ & \\
Pefloxacin & 150 & S. aureus & $19.20 \pm 4.33$ & & & \\
(PEF) & 55 & S. epidermidis & $19.88 \pm 4.33$ & 2.37 & $>0.05$ & \\
& 136 & Bacillus species & $16.00 \pm 5.94$ & & & \\
Sperfloxacin & 150 & S. aureus & $20.14 \pm 5.67$ & & & \\
(SPM) & 55 & S. epidermidis & $17.75+3.20$ & 1.51 & $>0.05$ & \\
& 136 & Bacillus species & $22.80 \pm 9.09$ & & & \\
Ofloxacin & 150 & S. Aureus & $23.97 \pm 4.22$ & & & Staph. \\
(OFX) & 55 & S. epidermidis & $19.88 \pm 3.52$ & 5.66 & $<0.05$ & \\
& 136 & Bacillus species & $20.30 \pm 3.23$ & & & \\
Cefuroxime & 150 & S. aureus & $7.60 \pm 3.06$ & & & \\
(CXM) & 55 & S. epidermidis & $0.00 \pm 0.00$ & 1.41 & $>0.05$ & \\
& 136 & Bacillus species & & & & \\
Ceftazidime & 150 & S. Aureus & $0.00 \pm 0.00$ & & & \\
(CAZ) & 55 & S. epidermidis & $0.00 \pm 0.00$ & - & & \\
\hline
\end{tabular}

$\mathrm{N}=$ number of resistant bacterial isolates

$\mathrm{LSD}=$ Least significant difference 
Table 6: Comparative antibiotic susceptibility of gram negative bacteria isolated from

\begin{tabular}{|c|c|c|c|c|c|c|}
\hline $\begin{array}{l}\text { Antimicrobial } \\
\text { Agents }\end{array}$ & $N$ & Bacterial Isolates & $\begin{array}{l}\text { Zones } \\
\text { inhibition } \\
\text { Mean + SD }\end{array}$ & $F$ & $P$-value & $\begin{array}{l}\text { Most resistant } \\
\text { isolate by LSD }\end{array}$ \\
\hline \multirow{4}{*}{$\begin{array}{l}\text { Ciprofloxacin } \\
\text { (CIP) }\end{array}$} & 28 & Proteus species & $25.50 \pm 3.31$ & \multirow{4}{*}{2.79} & \multirow{4}{*}{$>0.05$} & \multirow{29}{*}{$\begin{array}{l}\text { Pseudomonas } \\
\text { Species }\end{array}$} \\
\hline & 10 & Escherichia coli & $31.33 \pm 0.58$ & & & \\
\hline & 51 & Pseudomonas & $26.50+0.71$ & & & \\
\hline & 10 & spp. & $28.88 \pm 4.15$ & & & \\
\hline \multirow{6}{*}{$\begin{array}{l}\text { Pefloxacin } \\
\text { (PEF) }\end{array}$} & 9 & Klebsiella spp. & & & & \\
\hline & 28 & Proteus species & $19.40 \pm 3.10$ & & & \\
\hline & 10 & Escherichia coli & $25.67 \pm 4.04$ & & & \\
\hline & 51 & Pseudomonas & $18.50 \pm 0.71$ & 5.38 & $<0.05$ & \\
\hline & 10 & spp. & $18.88 \pm 2.58$ & & & \\
\hline & 9 & Klebsiella spp. & & & & \\
\hline \multirow{4}{*}{$\begin{array}{l}\text { Spefloxacin } \\
\text { (SPM) }\end{array}$} & 28 & Proteus species & $18.00+1.83$ & \multirow{5}{*}{1.50} & \multirow{4}{*}{$>0.05$} & \\
\hline & 10 & Escherichia coli & $25.00 \pm 3.46$ & & & \\
\hline & 51 & Pseudomonas & $18.50+4.95$ & & & \\
\hline & 10 & spp. & $19.63 \pm 5.97$ & & & \\
\hline \multirow{6}{*}{$\begin{array}{l}\text { Ofloxacin } \\
\text { (OFX) }\end{array}$} & 9 & Klebsiella spp. & & & \multirow{6}{*}{$>0.05$} & \\
\hline & 28 & Proteus species & $27.50 \pm 0.71$ & \multirow{5}{*}{1.86} & & \\
\hline & 10 & Escherichia coli & $24.67 \pm 0.71$ & & & \\
\hline & 51 & Pseudomonas & $23.00+1.41$ & & & \\
\hline & 10 & spp. & $23.88 \pm 4.54$ & & & \\
\hline & 9 & Klebsiella spp. & & & & \\
\hline \multirow{4}{*}{$\begin{array}{l}\text { Cefuroxine } \\
\text { (CXM) }\end{array}$} & 28 & Proteus species & $0.00 \pm 0.00$ & \multirow{4}{*}{2.19} & \multirow{4}{*}{$>0.05$} & \\
\hline & 10 & Escherichia coli & $0.00 \pm 0.00$ & & & \\
\hline & 51 & Pseudomonas & $0.00+0.00$ & & & \\
\hline & 10 & spp. & $1.59 \pm 3.78$ & & & \\
\hline \multirow{5}{*}{$\begin{array}{l}\text { Ceftazidime } \\
\text { (CAZ) }\end{array}$} & 9 & Klebsiella spp. & & \multirow{5}{*}{0.84} & \multirow{5}{*}{$>0.05$} & \\
\hline & 28 & Proteus species & $0.00 \pm 0.00$ & & & \\
\hline & 10 & Escherichia coli & $0.00 \pm 0.00$ & & & \\
\hline & 51 & Pseudomonas sp & $0.00+0.00$ & & & \\
\hline & $\begin{array}{l}10 \\
0\end{array}$ & Klebsiella spp. & $1.42 \pm 3.35$ & & & \\
\hline
\end{tabular}

$\mathrm{N}=$ number of resistant bacterial isolates

LSD $=$ Least significant difference 
Adekanle, Effedua, Oritogun, Adesiji \& Ogunledun

\section{DISCUSSION}

The number of documented outbreaks of human infections associated with the consumption of raw fruits and vegetables has increased in recent years (Akhtar et al., 2014; Uyttendaele et al., 2014). In this study, higher microbial contamination has been noticed in fat banana and water melon. This contamination may however not have serious consequences if the skins or rinds were to be peeled off before consumption. The microorganisnms present in fruits and vegetables as indicated in this study may be a direct reflection of the poor hygienic production and transport facilities.

The isolation of bacteria such as Staphylococcus aureus, Staphylococcus epidermidis, Bacillus species, Escherichia coli, Proteus species, Pseudomonas species, Klebsiella species, and fungi such as Malassezia species and Aspergillus species shows that fruits could act as a medium for the spread of both pathogenic and opportunistic microbes. These organisms isolated are also similar to those isolated by Mathur et al., 2014; Ankita, 2010; Eni et al., 2010. Isolation of Escherichia coli (coliforms) and enteric bacteria (Klebsiella species and Proteus species) from fruits \& vegetables suggested their likely-hood of faecal contamination (Issa-Zacharia et al., 2010), they could also arise from the use of human manure. Also, isolation of environmental isolates such as Pseudomonas, Bacillus and Aspergillus species, may be indicative of soil contamination. The isolation of skin commensals such Staphylococcus epidermidis, Staphylococcus aureus and Malassezia species (Abdelnoor et al., 1983), may serve as indicator of contamination by handlers, either during transportation or post-harvest processing. The resistance of isolated bacteria to Quinolones in this study was generally low, though a relatively higher resistance of $26.5 \%$ was recorded against Sperfloxacin, the reasons for this resistance to Sperfloxacin is unexplainable. Relative degree of resistance demonstrated by Staphylococcus epidermidis against Ofloxacin and Pseudomonas species against Pefloxacin has re-affirmed the report of Eni et al (2010).Bacterial isolates of fruits and vegetables from this study has also demonstrated an absolute resistance to Ceftazidine (100\%) and Cefuroxime (95.9\%). The implication of this is that these drugs would be of no benefit in the treatment of infections caused by any of the two micro-floras. It's a bit difficult to conclude on the origin of antibacterial resistance especially, those against Cephalosporins (i.e the Extended Spectrum Beta Lactam drugs). The prevalence of antibiotic resistant microbes in fruits and vegetables constitutes a great health risk in developing countries (Razzaq et al., 2014).

From our observations, it is evident that fruits and vegetables could act as a potential 
vehicle for the dissemination of antibiotic resistance, as well as medically important microorganisms. Future study should therefore be undertaken at molecular level in order to establish whether the antibiotic resistance in these floras of fruits and vegetables are plasmid-borne or not. And if the resistance gene is plasmid-borne, an attempt should therefore be made to establish whether the genes are transferable or not. The outcome of further studies will go a long way in answering questions on how antibiotic resistant genes may be transferred from micro flora of fruits and vegetables to the human intestinal flora, after consumption.

\section{REFERENCES}

Abdelnoor, A.M., Batshoun, R. and Roumani, B.M. (1983)."The Bacterial Flora of Fruits and Vegetables in Lebanon and the Effect of Washing on the Bacterial Content". Zbl Bakt Hyg I Abt Orig B, 177:342-349.

Akhtar, S., Sarker, M.R. and Hossain, A. (2014)."Microbiological Food Safety: A Dilemma of Developing Societies". Crit Rev Microbiol, 40:348-359.

Ankita, R. (2010). "Bacterial Load on Street Vended Salads in Juipur City, India". International J. Food safety, 12:136?139.

Downes, F.P. and Ito, K. (2001). "Compendium of Methods for the Microbiological Examination of foods, American Public Health As sociation" www.ajph.aphapublications.org/doi/pdf/10.2105/MBEF.0222.001

Eni, O.A., Oluwawemitan, I.A. and Solomon, O.U. (2010). "African Microbial Quality of Fruits and Vegetables Sold in Sango Ota, Nigeria".Journal of Food Science, 4(5):291-296.

Fatoba, I.O., Omotesho, O.A. and Adewumi, M.O. (2011)."Economics of Soybean Production Technology in the Guinea Savanna of Nigeria" Agrosearch. 11(1\&2): 39-48

Hannan, A., Rehman, R., Saleem, S., Khan, M.U., Qamar, M.U. and Azhar, H. (2014). "Microbiological Analysis of Ready-to-eat Salads Available at Different Outlets in Lahore, Pakistan". International Food Research Journal, 21(5):1797-1800.

Hanson, L.A., Zahn, E.A., Wild, S.R., Döpfer, D., Scott, J. and Stein, S., (2012)."Estimating Global Mortality from Potentially Foodborne Diseases: An Analysis Using Vital Registration Data". Population Health Metrics, 10 (5)

Issa-Zacharia, A., Kamitani, Y., Muhimbula, H.S. and Ndabikunze, B.K. (2010)."A Review of Microbiological Safety of Fruits and Vegetables and the Introduction of Electrolyzed Water as an Alternative to Sodium Hypochlorite Solution"African Journal of Food Science, 4(13):778-789.

Jeddi, M.Z., Yunesian, M., Gorji, M.E., Noori, N., Pourmand, M.R. and Khaniki, G.R.J. (2014). "Microbial Evaluation of Fresh, Minimally-processedVegetables and Bagged Sprouts from Chain Supermarkets". J Health Popul Nutr, 32(3):000-000. 
Jung, Y., Jang, H. and Matthews, K.R. (2014)."Effect of the Food Production Chain from Farm Practices to Vegetable Processing on Outbreak Incidence. Microbial Biotechnology, 7(6):517-527.

Mathur, A., Joshi, A. and Harwani, D. (2014)."Microbial Contamination of Raw Fruits and Vegetables".Internet Journal of Food Safety, 16:26-28

Nwachukwu, E. and Chukwu, C.M. (2013). "Effect of Chemical Treatments on the Microbial Load of Fruits and Vegetables"Int JAppl Microbiol Biotechnol Res, 1:16-19.

Olayemi, A.B. (2007). "Microbiological Hazards Associated with Agricultural Utilization of Urban Polluted River Water". International J. Enviro. Health Res, 7(2):149-154.

Razzaq, R., Farzana, K., Mahmood, S. and Murtaza, G. (2014). "Microbiological Analysis of Street Vended Vegetables in Multan City, Pakistan: A Public Health Concern". Pakistan J. Zool, 46(4):1133-1138,

Senjuti, J.D., Feroz, F., Tahera, J., Das, K.K., Noor, R. (2014)."Assessment of Microbiological Contamination and the Invitro Demonstration of the Anti-bacterial Traits of the commonlyAvailable Local Fruit Blend within Dhaka Metropolis".Journal of Pharmacognosy and Phytochemistry, 3(1): 73-77.

Uyttendaele, M., Moneim, A.A., Ceuppens, S. and Tahan, F.E. (2014)."Microbiological Safety of Strawberries and Lettuce for Domestic Consumption in Egypt".J Food Process Technol, 5:308. doi:10.4172/2157-7110.1000308

Vanderzant, C. and Splettstoesser,Eds (1993). Compedium of Methods for the Microbiological Methods for the Standard Method for Examination of Foods (MMEF). 